\title{
Bench Scale Investigation of Factors Influencing in Trihalomethanes Formation in Tetova's Drinking Water: Winter Season
}

\author{
Bujar H. Durmishi ${ }^{1 *}$, Arianit A. Reka ${ }^{1}$, Ahmed Jashari ${ }^{1}$, Murtezan Ismaili ${ }^{1}$, \\ Agim Shabani $^{1}$, Arbana Durmishi ${ }^{1}$ \\ ${ }^{1}$ State University of Tetova,Faculty of Natural Sciences and Mathematics, Department of Chemistry, \\ Ilindeni Str. Tetova, Republic of Macedonia \\ *bujar.durmishi@unite.edu.mk
}

\begin{abstract}
During the treatment process of drinking water, chlorine reacts with the organic matter present in water and forms various disinfection by-products (DBPs) such as trihalomethanes (THMs) and haloacetic acids (HAAs). The high content of THMs in the drinking water may be cancerogenic for humans and this has resulted in significant scientific and public concern. The aim of this paper was to determine the factors that have an impact on THM formation in the drinking water in the city of Tetova for the winter season 2011. Results of this research have shown that during high contact time, temperature, $p H$ and chlorine dosage, more THMs were formed. Based on the examined factors, results show that contact time, $p H$ and the chlorine dosage were crucial and had a significant role in THM formation. The presence of THMs was determined with UV-VIS spectrophotometry. This was the first study that researched the factors that impact the formation of THMs in the drinking water in the Republic of Macedonia. The study results match conclusions reached by previous research in the field.
\end{abstract}

Keywords: Bench Scale Investigation, Drinking Water, UV-VIS Spectrophotometry, THMs.

\section{INTRODUCTION}

The quality of drinking water is an essential factor for human health. In this respect, the monitoring of organic compounds in drinking water is of significant importance, since these compounds are harmful to human health [1]. The most dangerous organic compounds in drinking water are disinfection byproducts (DBPs) whose main sub-group is trihalomethanes (THMs) which are proven cancerogenous to humans [2]. The presence of THMs in drinking water in the last decades has caused great concern due to their cancerogenous properties. The monitoring of THMs formation is crucial in order to make sure that the drinking water quality meets acceptable safety levels. Therefore, actions to reduce THMs should be encouraged, while water disinfection remains uncompromised [3].

Studying the various factors that influence the formation of THMs is of great significance in reaching the right balance. Some factors have an impact on their potential formation, such as: $\mathrm{pH}$, temperature, contact time, chlorine dosage, natural organic matter (NOM), residual chlorine and concentration of bromides $[4,5,6]$. In order to minimise the formation of THMs there should be a greater understanding of the parameters that trigger their formation.

Each factor has specific significance in the formation of THMs. Generally, higher concentrations of THMs are expected when there are higher values of the abovementioned parameters [7]. Thus, with the increase of $\mathrm{pH}$ and contact time, there is a significant increase of THMs [8]. With the increase of temperature, the reaction kinetics is affected and the chlorine consumption is increased, which in turn leads to formation of THMs [9]. It is reported that the increase of chlorine dosage has a positive impact on the formation of THMs. The same effect is due to increase of NOM and temperature. The presence of bromide ion changes the specification of THMs towards many bromides; while the increase in $\mathrm{pH}$ increases the formation of some THMs while it inhibits the formation of, for example, haloacetonitriles and haloketones [8]. The type of untreated water has also an impact on the levels of THMs. In general, underground waters are protected from the impact of NOM. The varying levels of disinfection by-products precursors in rivers and lakes depends on geological factors, physical factors and the environment (trophic phase, the characteristic soil, the size of the lake, river size etc.) [7]. 
The aim of this article was the bench scale investigation of factors that impact the formation of THMs in the drinking water in the city of Tetova during the winter season of 2011.

\subsection{Factors That Impact the Formation of THMs - Literature Review}

\subsubsection{Types of Disinfectants}

All disinfectants used in water treatment systems have their advantages and disadvantages. Freely available chlorine is very effective in pathogen deactivation, however, it produces high concentrations of THMs. Chloramines are weaker disinfectants, but they produce lower DBPs. Ozone is another disinfectant and it does not produce DBPs, but its effectiveness decreases after spreading in the water supply network. UV rays have shown to be effective in the deactivation of pathogens and do not produce DBPs, but similarly to ozone do not produce residues in the water supply network.

The best ratio of $\mathrm{Cl}_{2}: \mathrm{N}$ when treating with chloramine, depends on the quality of the raw water. The type and concentration of humus matter present in raw water are the most significant parameters that dictate which ratio of $\mathrm{Cl}_{2}: \mathrm{N}$ is the most adequate. During research on disinfection with chloramine, Diehl et al. were able to determine higher levels of THMs when disinfection of water was performed with chloramine in a ratio $\mathrm{Cl}_{2}: \mathrm{N}$ 7:1 [10]. The ratio $\mathrm{Cl}_{2}: \mathrm{N}$ 3:1 is the ideal ratio in order to control the formation of DBPs, however, this ratio is not sufficient to control bacterial growth.

\subsubsection{Concentration of Disinfectants or Chlorine Dosage}

Numerous scientists have studied the effect of concentration of disinfectants on the formation of THMs $[11,12]$. Studies have shown that an increase in the concentration of disinfectants, results in an increase of THMs. For example, Singer et al., conducted a study in Northern Carolina in eight conventional plants where water was treated with chlorine [13]. Treatment plants with high doses of chlorine showed average presence of TTHMs at $52 \mu \mathrm{g} / \mathrm{L}$, while the plant that used lower doses of chlorine showed averages of THMTs at $19 \mu \mathrm{g} / \mathrm{L}$.

\subsubsection{The Nature and Concentration of NOM}

The properties of NOM play a significant role; hence the aromatic content in the NOM increases the formation of THMs [14]. Singer conducted a study on five humic and fulvic extracts [15]. The extracts were uniformly chlorinated and were tested for presence of DBPs. Chlorine consumption and the yield of DBPs were relatively low for the ones with humic acid, as a result of the presence of aromatic carbon. The further examination showed a linear ratio of chlorine consumption and content of aromatic carbon of various humic and fulvic acids. Besides, the NOM contains hydrophobic and hydrophilic materials, the nature and dispersion of which can change from various vegetation and different species of algae in water. In a study conducted on eight water supply systems in North Carolina, Singer et al. showed how the increased concentration of total organic carbon (TOC) has an impact on TTHM levels [13]. Concentrations of TOC at $5.4 \mathrm{mg} / \mathrm{L}$ produced an average of $82 \mu \mathrm{g} / \mathrm{L}$ TTHMs, while a concentration average of TOC at $2.4 \mathrm{mg} / \mathrm{L}$ produced an average $39 \mu \mathrm{g} / \mathrm{L}$ of TTHMs.

\subsubsection{Contact Time}

A number of studies have been performed in order to determine the impact of contact time with the formation of THMs. These studies have shown that with the increase of contact time, there is an increase in the concentration of TTHMs [16, 17, 18, 19]. Chen and Weisel have conducted experiments in order to determine the concentrations of DBPs in a conventional water treatment plant where chlorine was used as a disinfectant [20]. They collected more than 100 samples in four groups; each group was for a certain contact time from the disinfection point. Average concentrations of TTHMs in days zero, one, two and three or more weere $25 \pm 14 \mu \mathrm{g} / \mathrm{L}, 30 \pm 16 \mu \mathrm{g} / \mathrm{L}, 29 \pm 15 \mu \mathrm{g} / \mathrm{L}$, and $30 \pm 14 \mu \mathrm{g} / \mathrm{L}$, respectively. These results showed that with the increase of contact time, there was an increase of THMT concentration, whereasconcentrations of HAAs decreased. Similar results were presented by LeBel et al., who performed an experiment on a conventional water treatment plant where chlorine was utilized as the primary and secondary disinfectant [21]. Four sample points were determined. The levels of TTHMs in the first, second, third and fourth point were as follows: 24.8 $\mu \mathrm{g} / \mathrm{L}, 37.5 \mu \mathrm{g} / \mathrm{L}, 48.4 \mu \mathrm{g} / \mathrm{L}$ and $61.4 \mu \mathrm{g} / \mathrm{L}$. Results showed that levels of THMs increased as the distance from the treatment plant increased. Gallard and von Gunten performed experiments on natural waters and solutions with humic matter in order to determine the kinetics of formation of THMs and chlorine consumption [17]. They concluded that the formation of THMs increases with contact time. 


\subsubsection{Temperature}

A lot of research has been done in order to determine the impact of temperature in the kinetics of THM formation. Studies have shown that an increase in temperature results in an THM increase as well. However, the results are not conclusive as there have been contradictory results during some studies. Nieminski et al., reviewed the TTHMs concentrations during four seasons in 14 conventional water storage units where chlorine is used as a disinfectant [22]. The average levels of TTHMs for the summer, autumn, winter and spring season were 32.1, 28.7, 17.6 and $16.5 \mu \mathrm{g} / \mathrm{L}$, respectively. The study showed higher concentrations during summer and autumn, while lower concentrations were recorded in winter and spring. Chen and Weisel collected 144 samples of water between November 1991 and October 1993 from the water system Elizabethtown, N. J., which uses chlorine for disinfection [20]. Samples were collected during all seasons. Levels of TTHMs in winter were 14 \pm 4 $\mu \mathrm{g} / \mathrm{L}$, whereas in summer $33 \pm 13 \mu \mathrm{g} / \mathrm{L}$. Concentrations of HAAs in winter and summer were $24 \pm 6$ $\mu \mathrm{g} / \mathrm{L}$ and $26 \pm 8 \mu \mathrm{g} / \mathrm{L}$, respectively. The research conducted by Chen and Weisel showed that levels of TTHMs were considerable high during the summer, while the levels of HAAs were the same during the whole year.

\subsubsection{Temperature/Season}

When temperatures increase, reactions are faster and a higher dosage of chlorine is required, which in turn leads to an increase in the formation of THMs. Therefore, THM concentrations are higher in summer comparedto winter $[9,23,22,24,20,25]$. In winter months concentrations of THMs are lower due to lower water temperatures and lower values of NOM in water. In such conditions the sufficient dosage of chlorine for the water system is also lower. Golfinopoulos studied the appearance of THMs in the public water supplies in Greece [26]. Each water supply system, in general had lower TTHMs concentrations during the winter season and spring season, whereas the concentrations were much higher during summer and autumn. Higher dosages of chlorine in summer and autumn (in order to prevent microbiological concerns), in combination with warm water temperatures, resulted in higher concentrations of TTHMs.

\subsection{7.pH}

Several studies have been conducted in order to determine the impact of $\mathrm{pH}$ in the concentration of THMs in water supply systems. Studies show that increases in $\mathrm{pH}$, result in increased THMTs concentrations. Concentrations of HAAs are not $\mathrm{pH}$ dependent [27, 28, 29]. Diehl et al., performed a set of experiments to determine the effect of $\mathrm{pH}$ in the formation of DBPs in water supply systems that are treated with chloramines [10]. TTHMs were observed in values of $\mathrm{pH}$ at 6,8 and 10 and the results obtained were $161 \mu \mathrm{g} / \mathrm{L}, 259 \mu \mathrm{g} / \mathrm{L}$ and $295 \mu \mathrm{g} / \mathrm{L}$, respectively. Results show that there is a positive correlation between $\mathrm{pH}$ and TTHMs levels. Nieminski et al.. assessed 35 water treatment systems in Utah, where chlorine was used as a disinfectant [22]. TTHMs values at $\mathrm{pH} 5.5$ were 39.9 $\mu \mathrm{g} / \mathrm{L}$. At $\mathrm{pH} 8.46$, TTHMs levels were $49.8 \mu \mathrm{g} / \mathrm{L}$. The obtained results support the conclusion that higher $\mathrm{pH}$ values increase TTHMs concentrations.

\subsubsection{Concentrations of Total Organic Carbon}

Some researchers have studied the impact of total organic carbon (TOC) concentrations in the formation of THMs. The results show that a high concentrationof TOC increases the formation of THMs. Singer et al.,researched eight water treatment systems in North Carolina. At $5.4 \mathrm{mg} / \mathrm{L}$ concentrations of TOC, $82 \mu \mathrm{g} / \mathrm{L}$ of TTHMs were present; while at $2.4 \mathrm{mg} / \mathrm{L}$ of TOC the TTHMs values recorded were $39 \mu \mathrm{g} / \mathrm{L}$ [30]. These results showed that increased TOC concentrations result in TTHM concentration increases.

\subsubsection{Concentration of Bromides}

Studies that examine the impact of the concentration of bromides in the formation of THMs have shown that increasing the concentration of bromide also increases the concentration of TTHMs. Raw waters, where the concentration of bromides is high, and where disinfection is done with chlorine, will form more brominated THMs due to the reaction of bromides with organic matter. Diehl et al., tested the effect of the levels of bromides in the formation of TTHMs. Results showed that with an increase in the concentration of bromides yields an increase in the formation of TTHMs. In a treatment plant, where chloramine was utilized as a disinfectant (ratio $\mathrm{Cl}_{2}: \mathrm{N} \mathrm{5:1}$ and $\mathrm{pH}=6$ ) the 
concentration of TTHMs in water without bromides was $14.8 \mu \mathrm{g} / \mathrm{L}$, while after the addition of bromides, the concentration increased to $40.2 \mu \mathrm{g} / \mathrm{L}$ [11]. In the presence of bromide ion, more brominated THMs are formed, as well as mixed chloro-bromo THMs [27, 31]. In the presence of bromide ion, chlorine in the form of $\mathrm{HOCl}-\mathrm{OCl}^{-}$oxidizes the bromide ion into $\mathrm{HOBr}-\mathrm{OBr}^{-}$. The mixture of $\mathrm{HOCl}$ and $\mathrm{HOBr}$ yields to the formation of chlorinated-bromated by-products [5].

\section{MAterials AND Methods}

As mentioned above, there are many factors that affect the formation of THMs. Previous studies have shown that the main variables affecting the formation of THMs are contact time, temperature, $\mathrm{pH}$, total organic carbon, and chlorine dosage among others. The aim of this research was to assess the importance and the effect of variables in the formation of THMs in the drinking water of the city of Tetova. The experimental bench scale study has been performed in order to observe how the most important factors affect the formation of THMs. For this reason, we selected the following main factors: contact time, temperature, $\mathrm{pH}$ and chlorine dosage. Measurements were performed during the winter season in 2011, while the determination of THMs was performed with UV-Vis spectrophotometry.

\subsection{The Effect of Contact Time}

Samples of raw water (from the water reservoir prior to chlorination) have been treated with chlorine concentration of $6 \mathrm{mg} / \mathrm{L}$, in $\mathrm{pH}=7$ at room temperature. The reaction was recorded at the following time intervals: $0.5,1,2,3$ and 4 hours. THMs were measured at the end of each interval.

\subsection{The Effect of Temperature}

Samples of raw water (from the water reservoir prior to chlorination) have been treated with chlorine concentration of $6 \mathrm{mg} / \mathrm{L}$, in $\mathrm{pH}=7$, and then placed in a water bath at different temperatures and different contact times - temperatures of $10,20,30{ }^{\circ} \mathrm{C}$ at 1,2 and 3 hour intervals for each sample. THMs were analyzed at the end of each interval.

\subsection{The Effect of $\mathbf{p H}$}

Samples of raw water (from the water reservoir prior to chlorination) have been treated with chlorine concentration of $6 \mathrm{mg} / \mathrm{L}$, in different pH levels: $6,7,8$ and 9 , whilst using $0.01 \mathrm{~N}$ solution $\mathrm{H}_{2} \mathrm{SO}_{4}$ or $\mathrm{NaOH}$. Then samples were kept at room temperature and the reaction was followed for 1,2 and 3 hours for each sample. THMs were analyzed at the end of each interval.

\subsection{The Effect of Chlorine Dosage}

Samples of raw water (from the water reservoir prior to chlorination) have been treated with different dosages of chlorine concentration of 6,10 and $15 \mathrm{mg} / \mathrm{L}$. Each sample was tested in three different contact times: 1, 2 and 3 hours, while the reaction has been carried out at room temperature and $\mathrm{pH}=7.0-7.5$. THMs were analyzed at the end of each interval.

\section{Results AND Discussions}

Results of this research are presented in Tables $1-4$ and figures $1-4$.

\subsection{The Effect of Contact Time}

The dependence of THMs from the contact time is presented in Table 1 and Figure 1. From the shown results, we can conclude that the contact time has a significant impact on the formation of THMs. The results, also show that there was a linear dependency amongst the contact time and the formation of THMs. Based on shown results, formation of THMs was higher at the contact time of 0.5 hours (38.47 $\mu \mathrm{g} / \mathrm{L}$ ) meaning that half of the concentration of THMs was formed in this timeframe (4 hours). In the remaining contact time (1, 2, 3 and 4 hours) the concentration of THMs was increased, however not at high concentrations.

Table1. Dependency of THMs formation from the contact time

\begin{tabular}{|c|c|c|c|c|c|}
\hline \multirow{2}{*}{ Winter } & \multicolumn{5}{|c|}{ Contact time (h) } \\
\cline { 2 - 6 } & 0.5 & 1 & 2 & 3 & 4 \\
\hline THM $(\mu \mathrm{g} / \mathrm{L})$ & 38.47 & 41.56 & 58.63 & 72.42 & 83.28 \\
\hline
\end{tabular}




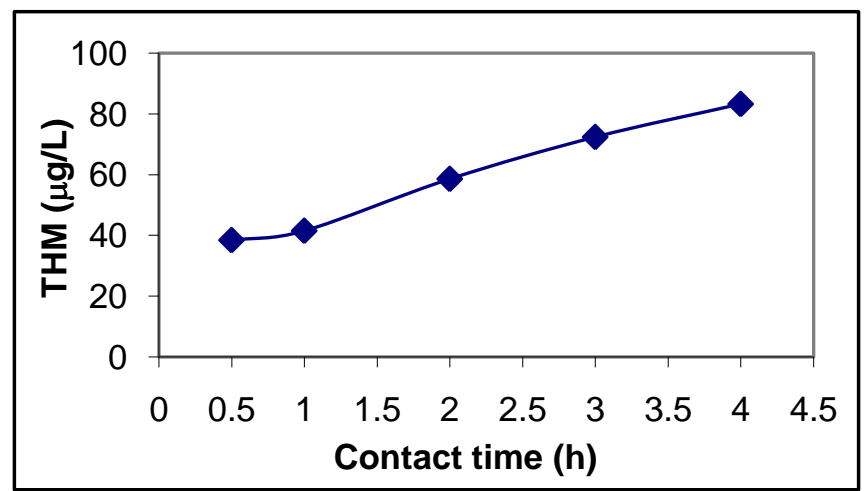

Fig1. The impact of contact time in the formation of THMs

\subsection{The Effect of Temperature}

The dependency of THMs formation from the contact time and temperature is shown in Table 2 and Figure 2. Frome the results, we can clearly see that the temperature has a significant impact on the formation of THMs. More specifically, it can be concluded that there is a linear dependency between temperature and the formation of THMs. The results show that the formation of THMs was higher at $30{ }^{\circ} \mathrm{C}(52.36 \mu \mathrm{g} / \mathrm{L}$ for contact time $3 \mathrm{~h}, 43.68 \mu \mathrm{g} / \mathrm{L}$ for contact time $2 \mathrm{~h}$ and $32.61 \mu \mathrm{g} / \mathrm{L}$ for contact time $1 \mathrm{~h}$ ). The increase of the concentration of THMs was more evident in the $20-30^{\circ} \mathrm{C}$ interval.

Table2.The dependency of THMs formation from the contact time and temperature

\begin{tabular}{|c|r|r|r|}
\hline Winter & \multicolumn{3}{|c|}{ Temperature ( ${ }^{\mathbf{0}} \mathbf{C}$} \\
\hline Contact time & 10 & 20 & 30 \\
\hline $1 \mathrm{~h}$ & 12.73 & 18.65 & 32.61 \\
\hline $2 \mathrm{~h}$ & 26.48 & 29.42 & 43.68 \\
\hline $3 \mathrm{~h}$ & 32.37 & 37.82 & 52.36 \\
\hline
\end{tabular}

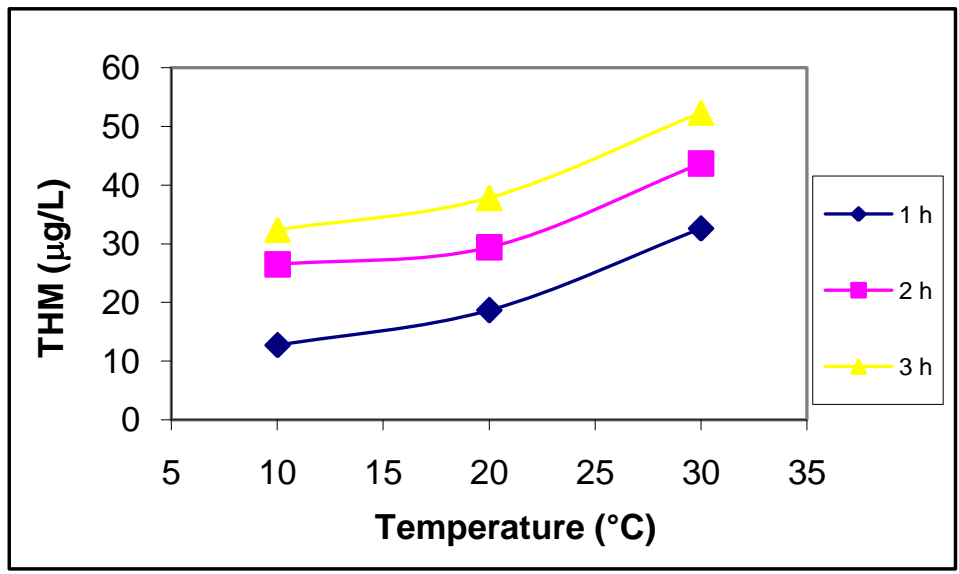

Fig2. The effect of temperature in the formation of THMs

\subsection{The Effect of $\mathbf{p H}$}

The results of the dependency of the formation of THMs from the contact time and $\mathrm{pH}$ are given in Table 3 and Figure 3. Examining the results, we can conclude that the $\mathrm{pH}$ value has a significant impact in the formation of THMs and that there is a linear dependency between the $\mathrm{pH}$ and the formation of THMs. The results show that the formation of THMs was higher at $\mathrm{pH}=9(98.56 \mu \mathrm{g} / \mathrm{L}$ for contact time $3 \mathrm{~h}, 86.25 \mu \mathrm{g} / \mathrm{L}$ for contact time $2 \mathrm{~h}$ and $72.38 \mu \mathrm{g} / \mathrm{L}$ for contact time $1 \mathrm{~h}$ ). The concentration of THMs increased almost linearly with the change of the $\mathrm{pH}$ value per unit.

Table3. Dependency of THMs formation from the contact time and $\mathrm{pH}$

\begin{tabular}{|c|r|r|r|r|}
\hline Winter & \multicolumn{4}{|c|}{ pH } \\
\hline Contact time & 6 & 7 & 8 & 9 \\
\hline $1 \mathrm{~h}$ & 18.43 & 36.78 & 58.16 & 72.38 \\
\hline $2 \mathrm{~h}$ & 36.32 & 58.27 & 71.84 & 86.25 \\
\hline $3 \mathrm{~h}$ & 52.62 & 64.51 & 83.74 & 98.56 \\
\hline
\end{tabular}




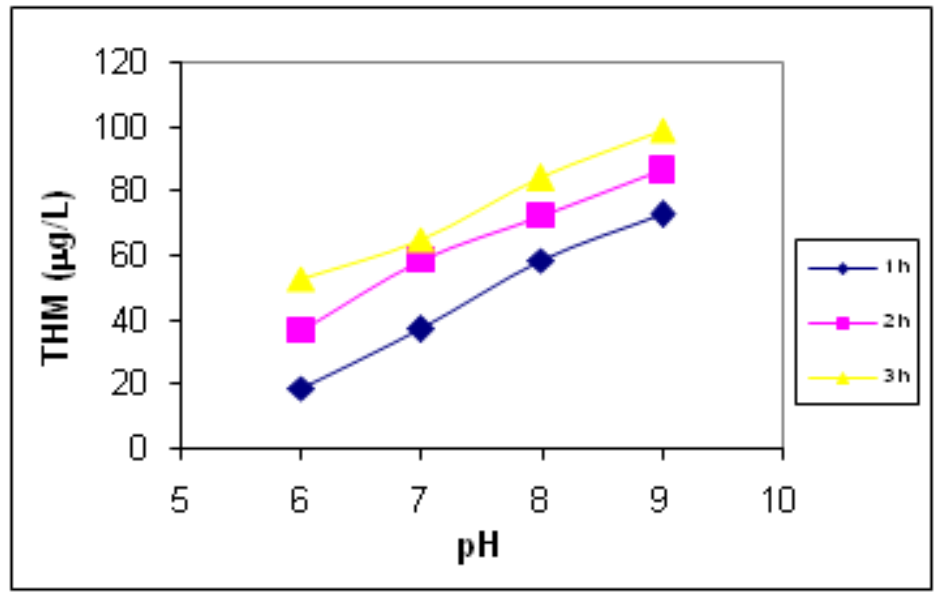

Fig3. The impact of $\mathrm{pH}$ in the formation of THMs

\subsection{The Effect of Chlorine Dosage}

Table 4 and Figure 4 show the results of the contact time and the chlorine dosage. Based on these results, it can be concluded that the chlorine dosage has a significant impact on the formation of THMs. In addition, there was a linear dependency between the chlorination dosage and THM formation. As the results show, the formation of THMs was higher at chlorine dosage of $15 \mathrm{mg} / \mathrm{L}$ $(62.38 \mu \mathrm{g} / \mathrm{L}$ for contact time $3 \mathrm{~h}, 58.23 \mu \mathrm{g} / \mathrm{L}$ for contact time $2 \mathrm{~h}$ dhe $54.61 \mu \mathrm{g} / \mathrm{L}$ for contact time $1 \mathrm{~h})$. The increase of THM concentration was more evident in the chlorine dosage interval between 6 to 10 $\mathrm{mg} / \mathrm{L}$, while in the interval $10-15 \mathrm{mg} / \mathrm{L}$ the concentration of THM was increasing at a slower rate.

Table4. Dependency of THMs formation form the contact time and chlorine dosage

\begin{tabular}{|c|c|c|c|}
\hline Winter & \multicolumn{3}{|c|}{ Chlorine dosage (mg/L) } \\
\hline Contact time & 6 & 10 & 15 \\
\hline $1 \mathrm{~h}$ & 28.52 & 47.83 & 54.61 \\
\hline $2 \mathrm{~h}$ & 36.42 & 51.71 & 58.23 \\
\hline $3 \mathrm{~h}$ & 41.17 & 57.45 & 62.38 \\
\hline
\end{tabular}

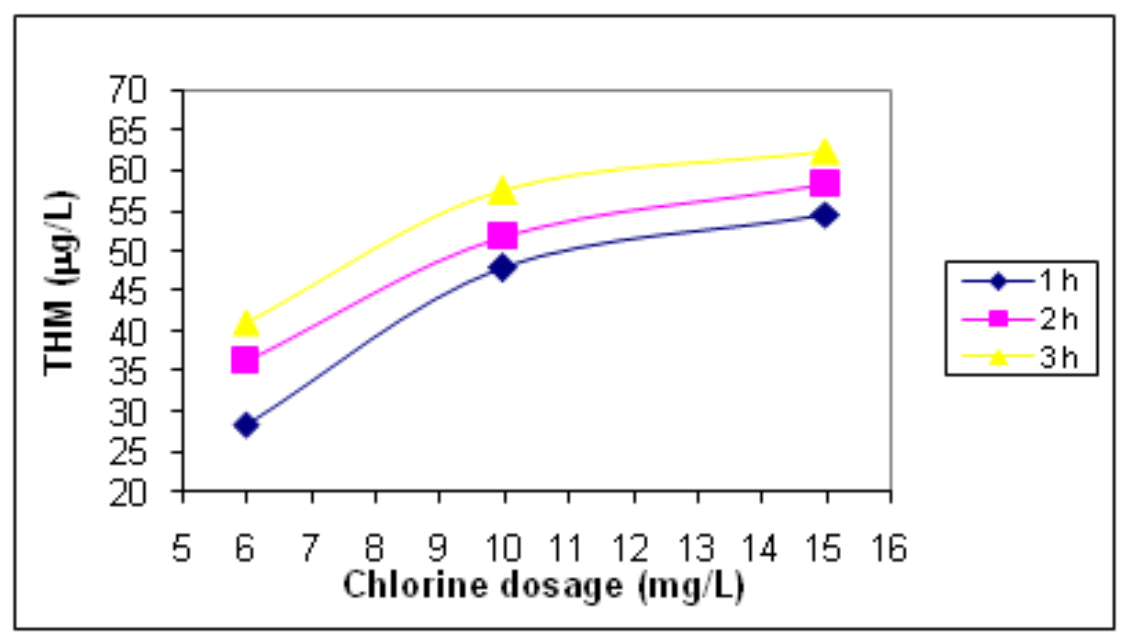

Fig4.The impact of chlorine dosage in the formation of THMs

\section{Conclusion}

The research conducted in this paper was a bench scale examination of the main factors that have an impact on the formation of THMs in the drinking water in the city of Tetova for the winter season of 2011. In order to determine the THM formation, bench scale experiments were performed. The factors that determine the formation of THMs were observed in controlled conditions. The observed factors were: contact time, temperature, $\mathrm{pH}$ and chlorination dosage. The results of this research have shown that the higher the values of these factors are, the higher the formation of THMswere. The contact time significantly impacts the generation of THMs and their highest formation was $38.47 \mu \mathrm{g} / \mathrm{L}$ for contact time of 0.5 hours, whereas for the other contact times $(1,2,3$ and 4 hours) the increase in THM concentration was at lower rates. The increase in temperature yields the formation of THMs, 
however, the impact of this factor has been lower compared to other factors. The $\mathrm{pH}$ values $(6,7,8$ and 9) showed the most significant effect on the formation of THMs and their content was increased with the increase of the $\mathrm{pH}$. The increase of chlorine dosages resulted in an increase of THMs, especially at the dosage interval 6 to $10 \mathrm{mg} / \mathrm{L}$.

\section{REFERENCES}

[1] Durmishi, B. H., M. Ismaili, A. Shabani, Sh. Abduli (2012). Drinking Water Quality Assessment in Tetova Region, American Journal of Environmental Sciences, 8 (2): 162-169.

[2] Durmishi H. Bujar, D. Vezi, M. Ismaili, A. Shabani, Sh. Abduli (2012). Seasonal Variation of Trihalomethanes Concentration in Tetova's Drinking Water (Part B), World Journal of Applied Environmental Chemistry, Volume 1, Issue 2: 42-52.

[3] Durmishi H. Bujar, Daut Vezi, Murtezan Ismaili, Agim Shabani and Shemsedin Abduli (2012). Trihalomethanes in Tetova's Drinking Water, Journal of Chemical, Biological and Physical Sciences, Section A: Chemical Science, Volume 3, Issue 1, 128-137.

[4] Zazouli, M. A., Nasseri, S., Mahvi, A. H., Mesdaghinia, A. R., Younecian, M., Gholami, M. (2007a). Determination of Hydrophobic and Hydrophilic Fractions of Natural Organic Matter in Raw Water of Jalalieh and Tehranspars Water Treatment Plants (Tehran). J. AJ. Applied. Sci., 7 (18), 2651-2655.

[5] Nikolaou, A. D., Golfinopoulos, S. K., Lekkas, T. D. and Kostopoulou, M. N. (2004a). DBP Levels In Chlorinated Drinking Water: Effect Of Humic Substances. Environmental Monitoring and Assessment, 93, 301-319.

[6] Golfinopoulos, S. K., and Arhonditsis, G. B. (2002). Multiple regression models: A methodology for evaluating trihalomethane concentrations in drinking water from raw water characteristics. Chemosphere, 47, 1007-1018.

[7] Sadiq, R., and Rodriguez, M. J. (2004). Disinfection by-products (DBPs) in drinking water and predictive models for their occurrence: A review. Science of the Total Environment, 321, 21-46.

[8] Nikolaou, A. D., Lekkas, T. D., and Golfinopoulos, S. K. (2004). Kinetics of the formation and decomposition of chlorination by-products in surface waters. Chemical Engineering Journal, $100,139-148$.

[9] Williams, D. T., LeBel, G. L., and Benoit, F. M. (1997). Disinfection by-products in Canadian drinking water. Chemosphere, 34, 299-316.

[10] Diehl, A. C., Speitel, G. E., Symons, J. M., Krasner, S. W., Hwang, C. J. and Barrett, S. E. (2000). DBP formation during chloramination. Journal of American Water Works Association. 92, 4, 76-90.

[11] Rathbun, R. E. (1996). Regression equations for disinfection by-products for the Mississippi, Ohio and Missouri Rivers. Science of Total Environment,191, 235 -244.

[12] Singer P. C. (1994). Control of disinfection by-products in drinking water. J. Env. Engineer., 120, 727.

[13] Singer, P. C., Obolensky, A. and Greiner, A. (1995). DBPs in chlorinated North Carolina drinking waters. Journal of American Water Works Association. 87,10, 83-92.

[14] Harrington, G. (1997). Characteristics of natural organic matter and their Influence on alum coagulation, Ph.D. Dissertation. University of North Caroline.

[15] Singer, P. C. (1999). Humic substances as Precursors for Potentially Harmful Disinfection Byproducts. Water Science and Technology, 40, (9), 25-30.

[16] Gang, D., Clevenger, T. E., and Banerji, S. K. (2003). Relationship of chlorine decay and THMs formation to NOM size. Journal of Hazardous Materials, A96, 1-12.

[17] Gallard, H. and von Gunten, U. (2002). Chlorination of Natural Organic Matter: Kinetics of chlorination and of THM Formation. Water Research, 36, 65-74.

[18] Boccelli, D. L., Tryby, M. E., Uber, J. G. and Summers, R. S. (2003). A reactive species model for chlorine decay and THM formation under rechlorination conditions. Water Research, 37, 2654-2666. 
[19] Rodriguez, M. J., and Serodes, J. B. (2001). Spatial and temporal evolution of trihalomethanes in three water distribution systems. Water Research, 35, (6), $1572-1586$.

[20] Chen, W. J., and Weisel, C. P. (1998). Halogenated DBP concentrations in a distribution system. Journal of American Water Works Association, 90 (4), 151-163.

[21] LeBel, G. L, Benoit, F. M. and Williams, D. T. (1997). A one-year survey of halogenated disinfection by-products in the distribution system of treatment plants using three different disinfection process. Chemosphere. 34, 11, 2301-2317.

[22] Nieminski, E. C., Chaudhuri, S. and Lamoreaux, T. (1993). The occurrence of DBPS in Utah drinking waters. Journal of American Water Works Association, 85, 9, 98-105.

[23] Golfinopoulos, S. K., Kostopoulou, M. N., and Lekkas, T. D. (1996). THM formation in the high-bromide water supply of Athens. Journal of Environmental Science and Health, A31, 6781.

[24] Arora, H., LeChevallier, M. W., Dixon, K.L. (1997). DBP occurrence survey. Journal of American Water Works Association, 89, (6), 60 -68.

[25] Rodriguez, M. J., and Serodes, J. B. (2001). Spatial and temporal evolution of trihalomethanes in three water distribution systems. Water Research, 35, (6), 1572-1586.

[26] Golfinopoulos, S. K. (2000). The Occurrence of Trihalomethanes in the Drinking Water in Greece. Chemosphere, 41, 1761-1767.

[27] Pourmoghaddas, H., and Stevens, A. A. (1995). Relationship between trihalomethanes and haloacetic acids with total organic halogen during chlorination. Water Research, 29, 2059-2062.

[28] Krasner, S. W., McGuire, M. J., Jacangelo, J. G., Patania, N. L., Reagan, K. M., and Aieta, M. E. (1989). The Occurrence of Disinfection By-products in US Drinking Water. Journal of American Water Works Association, 81, (8), 41-53.

[29] Singer, P. C. (1999). Formation and Control of Disinfection By-Products in Drinking Water. Denver, CO, USA: American Water Works Association.

[30] Singer, P. C., Obolensky, A. and Greiner, A. (1995). DBPs in chlorinated North Carolina drinking waters. Journal of American Water Works Association. 87,10, 83-92.

[31] Krasner, S. W., Glaze, W. H., Weinberg, H. S., Daniel, P. A., and Najm, I. N. (1993). Formation and Control of Bromate During Ozonation of Waters Containing Bromide. Journal of American Water Works Association, 85, 1, 73-81. 